\title{
Nucený návrat domů. K proměně reflexe Josefa Bohuslava Foerstera v prvních letech Československé republiky
}

\section{Forced Return Home: The Change in Perception of Josef Bohuslav Foerster in the First Years of the Czechoslovak Republic}

Lenka Křupková / lenka.krupkova@upol.cz

Department of Musicology, Faculty of Arts, Palacký University Olomouc, CZ

\begin{abstract}
With the exception of Leoš Janáček, composers from the generation of the so-called Czech Modern Music scarcely succeeded in presenting their work abroad in the first years of the new Czechoslovak Republic. The foreign interest in composers was indicated especially by contracts concluded with prominent publishing houses, such as the Universal Edition in Vienna, progressively developing since 1901. While in 1909-1910 the publishing house discovers Josef Bohuslav Foerster, Josef Suk, and Vítězslav Novák, and invests in their work with the prospect of certain profit, after the First World War it focuses its attention on the new generation of composers and the previously unnoticed avant-garde Second Viennese School, as well as on Leoš Janáček. Foerster, who returns to his homeland after the quarter century spent outside the Czech country, has to accept the local environment which makes it difficult to stay in touch with prominent personalities of the European culture.
\end{abstract}

\section{Keywords}

Josef Bohuslav Foerster, Universal Edition, Change in perception, Czechoslovak Republic 
S výjimkou Leoše Janáčka se skladatelům generace tzv. české hudební moderny v prvních letech nové Československé republiky téměř nedařilo prezentovat svá díla v zahraničí. A s výjimkou Leoše Janáčka se žádnému ze skladatelů této generace, tedy J. B. Foersterovi, Vítězslavovi Novákovi, Josefovi Sukovi a Otakarovi Ostrčilovi nepodařilo po 1. světové válce vydávat svá nová díla v zahraničí. Indikátorem zájmu ciziny o skladatele byly především smlouvy uzavírané s významnými vydavatelskými domy, jakým byla od roku 1901 výrazně se etablující Univerzální edice (Universal Edition) ve Vídni. V průběhu prvních desetiletí 20. století se stává Univerzální edice renomovaným hudebním nakladatelstvím s pobočkami po celé Evropě i v zámoří. Hlavními jejími počiny do války bylo vydání Brucknerových symfonií, některých děl Richarda Strausse a postupné vydávání právě dokončených symfonií Mahlerových. V letech 1909-1910 vydavatelství objevuje také české skladatele J. B. Foerstera, Josefa Suka a Vítězslava Nováka. Na počátku 20. let se však začíná proměňovat vydavatelská strategie. Třebaže i tehdy Univerzální edice ve velké míře produkovala $\mathrm{v}$ dobře prodejných kapesních partiturách již prověřená díla skladatelů klasicko-romantické hudby, současně systematicky vytvářela svou značku vydavatelství orientovaného na soudobou avantgardu. Neváhala vstupovat do riskantních podniků a vydávala díla Arnolda Schönberga, Antona Weberna, Albana Berga, Bély Bartóka aj. Zatímco zájem vydavatelství o Janáčka přetrvává, čeští skladatelé, jako Novák a Foerster, se do žádné z těchto dvou kategorií nevešli.

$\mathrm{V}$ tomto př́spěvku ukážu na př́kladu Josefa Bohuslava Foerstera, jak se se vyvíjela jednak vnější recepce jeho díla, jež je reprezentovaná skladatelovou spoluprací s nakladatelem Univerzální edice, současně se také pokusím načrtnout proměnu jeho hodnocení ve skladatelově vlasti.

\section{Od nadšení k nesouladu}

J. B. Foerster uzavřel smlouvu s vydavatelstvím Universal Edition v roce 1909, tedy $\mathrm{v}$ šestém roce svého vídeňského pobytu. Možnosti vydávat díla u věhlasného nakladatele si Foerster velmi vážil, protože si byl vědom renomé této instituce a také podle vlastních slov zažil předchozí hořká odmítnutí svých skladeb u jiných významných nakladatelů. ${ }^{1}$ Smlouva s Univerzální edicí byla stejně jako v případě Vítězslava Nováka uzavřena na deset let. $\mathrm{V}$ průběhu této doby byla vydána starší i nová Foerstrova díla, z větších kompozic především Stabat mater, op. 56 ve verzi s varhanami (1910) i orchestrem (1916), 4. symfonie c moll, op. 54 (1924), symfonická báseň Mé mládí, op. 44 (1910), orchestrální suita V horách op. 7 (1910), 1. houslový koncert c moll op. 88 (1912 - klavírní výtah, 1912 - partitura), Ballata pro housle a orchestr, op. 92 (1917), partitura a klavírní výtah opery Evy s německým textem (1914), klavírní výtah oper Jessika (1909) a Nepřemoženi (1918), z komorních děl např. Klavírní trio č. 2 B dur, op. 38 (1919), 3. smyčcový kvartet C dur, op. 61 (1914), klavírní Impresse, op. 73 (1911 a 1918 - součástí tzv. Foersterova alba), Snění, op. 47, Erotory masky,

1 FOeRSTER, Josef Bohuslav. Poutnik v cizině. Praha: Orbis, 1947, s. 169. 
op. 98 (1916), Sonáta pro violoncello a klavír č. 2 c moll, op. 130, písňové cykly - např. Čtyřri pisně, op. 60b, Zářivé dni, op. 69, sborová díla - např. Posvěceni noci, op. 87/I, Abendlied, op. 89/1 ad. Foerster navázal intenzivní kontakt především s ředitelem Univerzální edice Emilem Hertzkou (1869-1932), o němž ve svých pamětech hovoří jako o muži řídké pronikavosti a širokého rozhledu. ${ }^{2}$ Oceňoval jeho umělecký i obchodní instinkt, jenž se podle něho naplno projevil už tím, že se stal nakladatelem Mahlerovým. V průběhu času se jejich vztah, jenž je možno zjistit ze vzájemné korespondence, proměňoval, od počátečního nadšení a pravidelného osobního kontaktu, přes ochladnutí kvưli polevujícímu zájmu o skladatele ze strany vydavatelství, až k závěrečnému lidskému smíru.

Foerster uvádí, že Univerzální edice přijala do tisku všechny skladby, které jí zadal. Seznam skladeb, jenž vydavatelství dává skladatel v září 1909 k dispozici, ${ }^{3}$ se však neshoduje s tím, co nakonec opravdu bylo v Univerzální edici vydáno, ${ }^{4}$ mimo jiné např̀ nedošlo k vydání symfonické suity Cyrano z Bergeracu, opery Debora, 1. a 3. symfonie ad. Foerster byl zpočátku ze spolupráce s vydavatelstvím nadšen, jak je zřejmé z korespondence s přítelem Alfredem von Schebkem. V září 1910 Schebkovi píše: „Včera byl jsem $v$ Edici a mluvil jsem s p. ředitelem Hetzkou, jenž je vždy stejně milý a projevuje ke mně velké sympatie. Držel ve v̌šem slovo, co řekl, že do nové sezóny vyjde, také vskutku bude vydáno." ${ }^{5}$ O měsíc později o něm píše: „Je to jemný člověk a můj skutečný př́tel [...] Musím Ti sděliti, že p. ř platit za provedení skladby dirigent José Eibenschütz] mně, povidal mi: že dost toho vašeho idealismu, je čas, abyste viděl za svou práci odměnu. Vidǐs z toho, že je mi vskutku nakloněn. " 6 Foerster nazývá Hertzku „kupeckým géniem“, když popisuje jeho podnikatelské aktivity mimo Univerzální edici: „Koupil v Grinzingu řadu polí, di̊m se zahradou, postavil tam asi šest vil, které již výhodně prodal, domek koupený od zahradnika dal si seř́iditi, zahradu rozšíril, a jeho pani tam zařídila ,zahradnickou školu“ pro dívky (s penzionátem). Má laciné pracovniky a květiny a zeleninu vozi denně do Vidně. Jeden čas měli i krám květinářský v Konzerthause. Pro ty své žačky potrebuje prý též ty brambory a máslo, pro dvůr, kde má pět vaječniků. Jak mi řekl, a 70 hus a kachen: kukuřici a $t$. $d$. " " Univerzální edice nejednala vždy v souladu s představami skladatele, problémy nastaly zvláště ve válečných letech. Foerster si např. stěžoval na její požadavek, aby platil $20 \%$ z tantiém mimo Národní divadlo: „Ptám se: zač? ,Jessika“ leži tam už skorem 8 let, ,Eva“ druhý rok, co udělala U. E. pro ty věci? Vydala je tiskem. Ty víš, jak!! Ale zase si řikám: nestará-li se Edice o provedení německé - nedostane těch $20 \%$ [...]." Foersterova nekonfliktní povaha mu mnohdy nedovolila prosadit své požadavky, Scheb-

2 Ibid., s. 171.

3 Korespondence J. B. Foerstera Emilu Hertzkovi, dat. 11. 10. 1909. Wiener Stadt- und Landesbibliothek, Handschriftensammlung, Archiv Universal Edition in Wien, J. B. Foerster, dopis č. 1.

4 Univerzální edice zakoupila z českých nakladatelství pro německé vydání klavírní úpravu opery Eva, klavírní cyklus Sněni a Sonátu pro violoncello a klavír, č. $1 \mathrm{f}$ moll, op. 45.

5 Korespondence J. B. Foerstera Alfredovi Schebkovi, dat. 21. 9. 1910. České muzeum hudby, Fond nenotových rukopisů, č. inv. G13219.

6 Ibid, dat. 3. 10. 1910, č. inv. G13221.

7 Ibid, dat. 15. 9. 1916, č. inv. G13356.

8 Ibid, bez dat. [1916], č. inv. G13409. 
kovi např. píše, že „u Hertzky pochodi jen ten, kdo dovede být hrubým a bezohledným“, k nimž řadí i svého pražského rivala Vítězslava Nováka: „Z Prahy (sám mi to ukazoval [Hertzka]) chtěji např, aby vydal klav. výtah nové opery od Nováka, pošlou mu ihned dopis se smlouvou a pevnými terminy od advokáta! Ředitel se rozzlobi, křiči, že si nedá poroučet, ale za týden už posilá manuskript do tisku! "9 Licenční podmínky se v průběhu let stávaly pro skladatele čím dál nevýhodnější, v případě opery Nepřemoženi dokonce uvažoval, že libreto českého textu i německého překladu nedá tomuto vydavatelství k dispozici, příteli Schebkovi o tom píše: „Vydá-li řed. Hertzka jednou libretto, bude již operu považovati za svou, a vís, jaké obtiže dělá, jde-li o vydáni i jen klavírního výtahu! - o partituře nemluvím. Jinými slovy: jsem mu, vydá-li text, již zavázán i hudbou. "10 Foerster později změnil názor a v roce 1918 klavírní výtah i s německým textem této opery v Univerzální edici vyšel.

\section{Touha po zahraničních provedeních}

Skladatel si byl totiž dobře vědom, že jen prostřednictvím známého nakladatele může dosáhnout provádění svých děl. Po úspěšném vídeňském provedení 4. symfonie v dubnu 1917, jehož se zúčastnil i ředitel Hertzka, ho žádá, aby dílo zaslal dirigentům Felixi Weingartenovi a Ferdinandu Loewemu, a prosadil tak další uvedení díla. Zdůvodňuje to tím, že další vídeňské provedení může přinést patřičné kritické ohlasy, jichž je zapotřebí k tomu, aby se dílo hrálo i za hranicemi. ${ }^{11}$ Foersterovou ctižádostí bylo dostat především opery na zahraniční jeviště. V roce 1916 požaduje po Univerzální edici, aby mu pomohla vyjednat podmínky k provedení orchestrální suity Ze Shakesepara a opery Jessika na shakespearovských slavnostech v USA. ${ }^{12} \mathrm{~K}$ americkému obecenstvu se mu nakonec podařilo dostat až prostřednictvím Jana Kubelíka, jemuž věnoval houslový koncert. ${ }^{13}$ Ani po návratu z Vídně do vlasti Foerster nepřestával usilovat o provedení svých děl v zahraničí. V dubnu 1922 Univerzální edice zasílá na Foerstrův pokyn klavírní výtahy a libreta Jessiky, Evy i Nepřemožených intendantovi Hansi Pichlerovi z městského divadla ve Freiburgu, od něhož získal příslib uvedení jedné z těchto oper v sezoně 1922/23. ${ }^{14}$ Když ani po dvou měsících nedostává žádnou reakci, ujištuje se, zda vydavatelství skutečně požadovaný operní materiál do divadla poslalo a vyslovuje domněnku, že v dané době patrně panuje nechut k provedení děl slovanských autorů. ${ }^{15}$ Freiburské divadlo si nakonec vybralo

9 Ibid, dat. 27. 9. 1916, č. inv. G13358.

10 Ibid, dat. 31. 12. 1916, č. inv. G13366.

11 Korespondence J. B. Foerstera Emilovi Hertzkovi, dat. 19. 4. 1917. Wiener Stadt- und Landesbibliothek, Handschriftensammlung, Archiv Universal Edition in Wien, J. B. Foerster, dopis č. 28.

12 Ibid., dat. 15. 1. 1916, dopis č. 21.

13 Po vydání Koncertu pro housle a orchestr c moll, op. 88 v Univerzální edici byla na dobu jednoho roku vyhrazena provozní práva výlučně Kubelíkovi. FOERSTER, op. cit., s. 197.

14 Korepondence J. B. Foerstera Emilovi Hertzkovi, dat. 26. 4. 1922. Wiener Stadt- und Landesbibliothek, Handschriftensammlung, Archiv Universal Edition in Wien, J. B. Foerster, dopis č. 39.

15 Ibid., dat. 1. 7. 1922, dopis č. 41. 
vídeňskou scénou prověřenou Evu, jejíž provedení se však několikrát přesunulo a nakonec k němu došlo až 20. 6. 1923 - jak Foerster hořce komentuje - „bohužel velmi pozdě pro tragickou operu, takřka zahozenou těsně prèd koncem sezony! Co se dá dèlat, [...] já mám vždycky smůlu “ ${ }^{16} \mathrm{O}$ Evu se měl ještě v roce 1926 zajímat Bruno Walter, jemuž na Foerstrovo přání vydavatelství zaslalo klavírní výtah do Berlína. ${ }^{17}$

\section{Nezájem vydavatele}

Foerstrův postřeh týkající se nezájmu německojazyčného prostředí o českou hudbu po vzniku samostatného státu byl namístě. Po odchodu z Vídně ustává rovněž uvádění jeho děl v dříve domovské Vídni. ${ }^{18}$ Skladatel Hertzku opakovaně informuje o hojných českých provedeních svých skladeb nebo operních reprízách a zve ho do Prahy, na což však ředitel stále méně reaguje. Na počátku roku 1920 Foerster Hertzkovi píše, že Nepřemoženi před vyprodaným publikem slavili již 15 . reprízu, ${ }^{19}$ láká ho na provedení Jessiky a Evy, jež jsou také právě na repertoáru. ${ }^{20} \mathrm{Na}$ konci roku 1920 předkládá výčet úspěšných provedení a dokazuje tím velký zájem o svou práci v právě vzniklém státě. Národní divadlo má na programu všechny výše zmíněné opery, Eva se líbila i v Plzni, Debora má být provedena v sezoně 1920/21 v Brně a rovněž v Praze nově nastudována. Také symfonická díla jsou pilně připravována. Jen za poslední tři měsíce právě probíhající sezony byla v Praze uvedena 1. a 4. symfonie, dále orchestrální suita V horách, symfonická báseň Jaro a touha, suita Ze Shakespeara, třikrát Cyrano, mají se ještě dávat Trilogie o Simsonovi, Písně na Rabíndranátha Thákura a Ballata $\mathrm{v}$ úpravě pro housle a orchestr, již chce Kubelík také provést na americkém turné. Také houslový koncert je v Praze hrán i dalšími znamenitými interprety, Foerster jmenuje primária Ševčíkova kvarteta Bohuslava Lhotského. V minulém týdnu se v Mozarteu uskutečnil „Foerstrův večer“, na kterém byla kromě písní (na Thákura, Záríivé dni atd.) provedena i houslová a violoncellová sonáta a 3. smyčcový kvartet. ${ }^{21}$

Těmito důkazy domácí popularity však Foerster Hertzku nepřesvědčil, Univerzální edice přestává mít zájem vydávat Foersterova díla, a to i těch, k jejichž vydání se v roce 1909 smluvně zavázala. V polovině roku 1920 žádá vydavatelství, aby pro pražské Orchestrální sdružení zaplatilo opis dosud nevydaných partitur Cyrana z Bergeracu a kantáty Mrtoým bratřim (Mortuis fratribus). Vysvětluje, že se jedná o spolek diletantů, jež provozuje

16 Ibid., dat. 15. 6. 1923, dopis č. 47.

17 Ibid., dat. 28. 10. 1926, dopis č. 55.

18 Foersterovo dílo se po jeho návratu do vlasti provádělo ve Vídni velmi sporadicky a výlučně v prostředí české menšiny - viz soupis provedení uvedený ve studii: REITEREROVÁ, Vlasta - VELEK, Viktor. K vídeňským létům (1903-1918) Josefa Bohuslava Foerstera. Hudebni věda, 2010, roč. 47, č. 2-3, s. 217.

19 Korespondence J. B. Foerstera Emilovi Hertzkovi, dat. 4. 1. 1920. Wiener Stadt- und Landesbibliothek, Handschriftensammlung, Archiv Universal Edition in Wien, J. B. Foerster, dopis č. 33.

20 Ibid., dat. 31. 3. 1920, dopis č. 34.

21 Ibid., dat. 26. 12. 1920, dopis č. 38. 
hudbu bezplatně a jen z lásky k umění. ${ }^{22}$ Když Univerzální edice odmítla tuto záležitost financovat, konstatuje rozzlobený Foerster, že vydavatelství vlastní dlouhých jedenáct let autorská práva k Cyranu z Bergeracu, aniž by nechalo vytisknout partituru nebo klavírní výtah, který je již dávno připravený k vydání. Přitom v Praze se tato skladba hraje každou sezonu, jen v té aktuální, to znamená za poslední dva měsíce, byla provedena již třikrát a posluchači se proto přirozeně ptají po klavírním výtahu. Vzniká tím škoda nejen jemu samotnému, ale také Edici, píše Foerster Hertzkovi. ${ }^{23}$ Později se k tomuto výčtu nerealizovaných vydání vrací: „Jednoho velmi lituji (v mém věku!), že to s vydáním mých větších děl jde tak pomalu (Cyrano leži v Edici 11 let, Jaro a touha 6 let, partitura IV. symfonie 9 let), “ a přidává výrok jednoho svého přítele (snad aby sám nepadl do podezření z řevnivosti), že „všechny partitury Novákovy již byly vydány $k$ jeho 50. jubileu, všechny jsou vyryty, kdežto všechny mé partitury bez výjimky byly vydány jen litograficky “.24 Ani na tyto výčitky však Univerzální edice nereagovala. Spolu s informací o dosavadních 34 reprízách Evy v aktuální sezoně oznamuje Foerster v červnu 1922 Hertzkovi, že Foerstrova společnost vydala klavírní výtahy Cyrana z Bergeracu, symfonické básně Jaro a touha a 3 . symfonie. ${ }^{25}$ Podobný osud stihl i kantátu Mrtvým bratřím, prvního díla dokončeného po skladatelově návratu do vlasti. V témže dopise Foerster řediteli připomíná, že kantáta leží v poslední korektuře ve Vídni a že dílo je po dvou úspěšných provedeních a někdejším zájmu hned několika velkých českých sborových těles odsouzeno do zapomenutí. O čtyři roky později znovu připomíná nutnost vydání tohoto díla, jež mělo být v roce 1928 provedeno na hudebním festivalu v Praze za účasti sboru sestaveného z 6000 zpěváků. ${ }^{26} \mathrm{~V}$ roce 1927 však Univerzální edice s konečnou platností rozhodla toto dílo nevydat, ${ }^{27}$ na což skladatel reaguje s patrnou hořkostí: „Skutečnost, že Univerzálni edice prïjme dílo, nechá je vyrýt, aby ho pak dala z ruky, je deprimujicí "28 Také tuto kantátu nakonec v roce 1929 vydala Foerstrova společnost.

Posledním Foersterovým dílem vydaným v Univerzální edici byla IV. symfonie. Aby k tomu po velkých průtazích v roce 1924 došlo, musel Foerster vydavatele usilovně podněcovat zprávami o úspěšných provedeních a zasíláním kritických ohlasů. Skladatel postupně přijímal skutečnost, že nepatří k tvůrcům, do nichž bylo ochotno vydavatelství investovat. Jeho skladby neměly šanci v zahraničí uspět a rozsahem omezený československý trh byl jen málo zajímavým obchodním cílem. Zvláště na počátku 20. let Foerster intenzivně prožíval příkoří, o nichž byl přesvědčen, že se mu ze strany Univerzální edice dějí, jak o tom svědčí i tyto řádky adresované Hertzkovi: „Nepř́ijemně se mě dotklo vyškrtnuti nebo ignorováni (vyjde to nastejno) mého jména a děl v anonci Univerzální edice na obálce časopisu Musiblätter des Anbruch, kde jsou vydavatelstvi doporučovány, moderni smyčcové kvar-

Ibid., dat. 30. 6. 1920, dopis č. 35 .

Ibid. 
tety' Je to úmysl? Musim si bohužel myslet, že to je úmyslné, protože obdobné chování následovalo ze strany Univerzálni edice už několikrát. Pan ředitel musel nejlépe vědět, kdo je tou pověrenou osobou, která vytváři tyto anonce pro časopis, v niž žádný autor Univerzálni edice nechybi, vyjma mě. "29 A dále o čtyři roky později: „Že moje jméno a má díla jsou už delši dobu Univerzálni edicí tak málo ceněny, že v soupisech a katalozich dokonce moje jméno chybi (viz niže soupis $v$ poslednim čisle Pult und Taktstock), lituji velmi, aniž bych v̌̌ak rozuměl di̊vodu, proč se tak děje. Je prece jen dobrá a špatná hudba a já jsem díla toho posledního druhu nikdy nenapsal."30

\section{Satisfakce ve vlasti}

J. B. Foerster se vrací natrvalo do Prahy v roce 1919. Třebaže byl po celé předchozí čtvrtstoletí integrovanou součástí německého kulturního prostředí jako hudební referent významných periodik a skladatel komponující svá vokální díla převážně na německé texty či se samozřejmými německými překlady, byl přivítán v nově vzniklém státě se všemi poctami. Nedostal se do veřejné nacionalisticky přiživované klatby, v níž se octl po svém návratu do vlasti Oskar Nedbal, ačkoli strávil v německém prostředí nepoměrně kratší dobu než Foerster. Výmluvně dokládá atmosféru vulgárních výpadů a vyřizování osobních účtů krátce po převratu tento citát z článku anonymního autora otištěného v Hudebni revue:

„Český svět byl mu príliš malý a Videň měla poskytnouti širší základnu pro rozmach jeho širokých ramenou a pro uplatnění jeho ctižádostivých plánů. V Praze ř́kal tomu, propagace české hudby v cizině a s velkým gestem ukazoval na odiv svoji mučednickou korunu, zatím co ve Vidni levou rukou psal dle osvědčených vzorů laciné operetky a pravou rukou dirigoval Beethovena a Goldmarcky a někdy také Dvořáka a Smetanu. Nebot' až na ojedinělé výjimky, jež potvrzuji pravidlo: dál než k těmto bezpečně uznávaným mistrưm (po ojedinělých pokusech se Sukem, Novákem a Foersterem) se Oskar Nedbal ve Vidni nedostal. Tento exponent české hudby na horké půdě vídeňské nescházel na žádném oficiálním koncertě, kde šlo o to blýsknout se v přizni mocných. A trpěl, chudák, tak dlouho svým češstvím, až objevil, že vlastně jest státním př́ślušnikem mad’arským a že jeho otec jest vlastně čistokrevný Němec... A s jemným smyslem pro konjunkturu, dř́ve než všichni ti drobni úřednici čeští, jako proni myš prìhotovil se, aby opustil tonouci koráb vídeřské státni flotilly. V prvých dnech státního prèratu objevil se mezi námi, navštívil řadu bývalých přátel, ale - diplomat - neudal cíle své cesty. Sondoval půdu, která se mu kdysi zdála tak sterilní. A odejel s nepořizenou. Ne: pro tyto pomocniky jsou hranice československého státu přece jen príliš těsné. "31

29 Ibid., dat. 3. 6. 1922, dopis č. 40.

30 Ibid., dat. 28. 10. 1926, dopis č. 55.

31 ANONYM. Směs. Očista. Hudebni revue, 1918-19, roč. 12, č. 3, s. 130. 


\section{Foerster a Hudební revue}

Tvrzení o Nedbalově řídkém provádění českých děl je v rozporu se skutečností, jak je patrno ze soupisu repertoáru Nedbalem řízeného Tonkünstlerorchestru Alexandra Buchnera, ${ }^{32}$ nebo i Foerstrových vzpomínek, ${ }^{33}$ a najdeme zde další nepravdy či zkreslení. Že se Foerster nestal terčem podobných výpadů, bývá přičítáno i jeho charakterovým vlastnostem - je zmiňována jeho „uvážlivá, laskavá a tolerantní povaha“. ${ }^{4}$ Až do svého návratu však Foerster nebyl ve své vlasti bezvýhradně přijímán, a to především ze strany dvořákovského tábora a jeho názorové platformy Hudební revue. Sám Foerster byl přesvědčen, že tento časopis jeho dílu staví četné překážky, v roce 1915 píše Alfredu Schebkovi: „Z Prahy jsem se př́ té př́ležitosti dozvěděl, že dosud, - tedy za 7 let, - prodalo se českého klav . výtahu, Evy“ celkem 212 exempláři. Kolosálni, vid’... Ovšem orgán Umělecké Besedy - „Hudebni Revue“ obává se co nejvice, aby svým čtenářum dokázala, že co nese mé jméno je - bez ceny. Jak se tedy diviti, že se „Eva“ neprodává! V divadle ji také nedávají, kde možno se snad i proti ní pracuje, venkovská divadla koupi jen nejnutnějši exempláře, (ačkoli autoru platí tantiémy neuvěritelně malé), tak to chodí. A při tom je to opera česká, jež měla nesporný ,úspěch ‘ a byla již provedena $24 \times . .{ }^{\text {“35 }}$ Foerster byl pravidelným čtenářem Hudební revue a sledoval kritické ohlasy na provedení či vydání svých děl. V hodnotící studii při příležitosti skladatelových padesátin v roce 1909 zdůrazňuje Karel Hoffmeister působnost německého prostředí na Foersterovu hudbu, jež staví do pozadí české vlivy, mluví o „nikterak silné invenci“, „nižší tvưrčí síle“, oceňuje však „kulturní rozhled skladatelův“. ${ }^{36}$ Opakovaně je recenzenty vytýkána absence folklorní charakteristiky v Evě ${ }^{37}$ ze srovnání s Janáčkovou Jeji pastorkyni zpravidla vychází Eva hůře, postavy se jevily být „charaktery pochybnými a nevyhraněnými“, oceňovaly se však lyrické partie opery. ${ }^{38}$ Ota Zítek v recenzi na klavírní Erotovy masky píše o chudé a fádní invenci a technicky nezajímavém a konvenčním díle, ${ }^{39}$ Deboře vytýká absenci dramatičnosti a př́lišnou konzervativnost ${ }^{40}$ a opakovaně je

32 BUCHNER, Alexander. Oskar Nedbal. Soupis pozůstalosti I. Praha: Národní muzeum v Praze. Divadelní oddělení, 1964.

33 Ve svých pamětech např. uvádí, že Nedbal „dovedl téměř bez výjimky od prvního do posledního koncertu, který dirigoval, zařaditi do svého programu dílo českého autora“. (FOERSTER, op. cit., s. 218.)

34 REITEREROVÁ - VELEK, op. cit., s. 168.

35 Korespondence J. B. Förstera Alfredovi Schebkovi, dat. 3. 3. 1915. České muzeum hudby, Fond nenotových rukopisů, č. inv. G 13222

36 HOFMEISTER, Karel. Rod Foersterů. Hudebni revue, 1909, roč. 2, č. 10, s. 495.

37 ŠTĚPÁN, Václav. Její pastorkyňa. Odpověd’ na článek prof. Nejedlého. Hudebni revue, 1916-17, roč. 10, č. 1, s. 38; Dr. PIHERT [Jindřich Pihert]. Z hudebního života. Národní divadlo. Foersterova Eva. Hudební revue, 1917-18, roč. 11 , č. 4 , s. 157-8.

38 Ibid.

39 ZÍTEK, Ota. J. B. Foerster. Erotovy masky. Op. 98. Pro klavír na dvě ruce. Vydala Universální edice. Hudebni revue, 1917-18, roč. 11, č. 2, s. 68-9.

40 „Máme tedy v Deboře dílo, které jest [...] umělecky však konservativní. Proto konservativním že nepřineslo žádnou novou, osobitou notu ani v prostředcích, ani ve výraze." ZÍTEK, Ota. J. B. Foerster: Debora. V novém nastudování za řízení Otakara Ostrčila. Hudebni revue, 1917-18, roč. 11, č. 8-9, s. 348-9. 


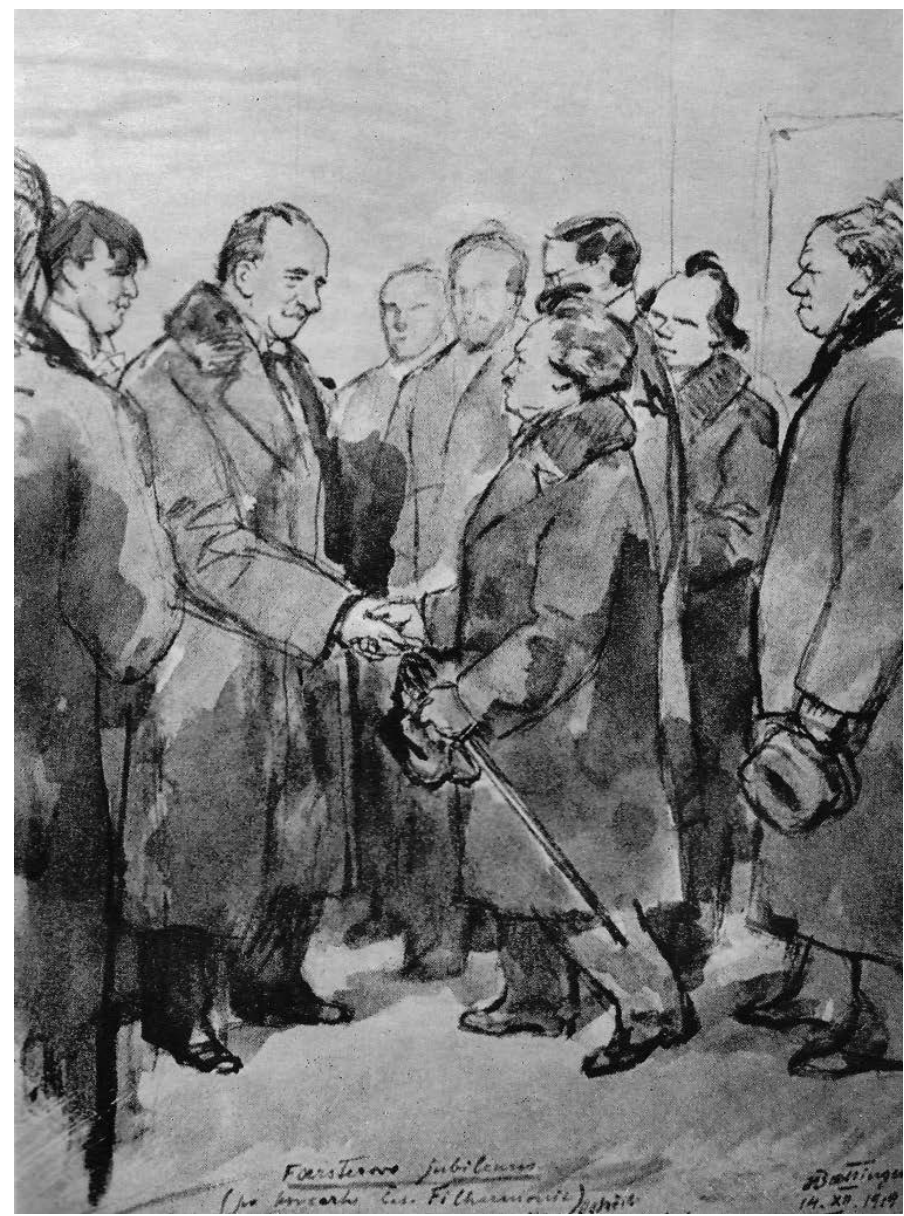

Obr. 1 Dr. Desiderius [Hugo Boettingerg]: Čeští hudebníci blahopřejí J. B. Foersterovi k šedesátce. Zdroj: BARTOŠ, Josef (red.). J. B. Foerster - Jeho životní pout' a tvorba 1859-1949. Praha: Orbis, 1949.

k němu kritický i Václav Štěpán, jako např. v recenzi na vydání Ballaty pro housle a orchestr v Univerzální edici, jíž vytýká nedostatečnou architekturu a formální nedostatky. ${ }^{41}$

$\mathrm{K}$ velké proměně hodnocení J. B. Foerstera a jeho hudby dochází na stránkách $H u$ debni revue ihned po jeho návratu - hlavní studie prosincového čísla časopisu věnované jeho jubileu se nesou již jen v oslavném a uctívajícím duchu. Patetický tón přinášejí řádky úvodního článku Anny Stretiové: „Jemu, Foersterovi, bylo neporozuměno a křivděno ze dvou

41 A dále také: „Severská tvrdost, démoničnost, vůbec ony prvky balladového obsahu, $k$ nimž patři síla, této balladě scházeji; kde se o ně Foerster přece snaži, jako např. ve vášnivě vzrušeném allegru affetuosu, upadá do konvenčnosti." ŠTĚPÁN, Václav. J. B. Foerster. Ballata pro housle a orchestr, op. 92, Universální edice, vyd. pro housle a klavír, 1917. Hudebni revue, 1917-18, roč. 11, č. 8-9, s. 345. 


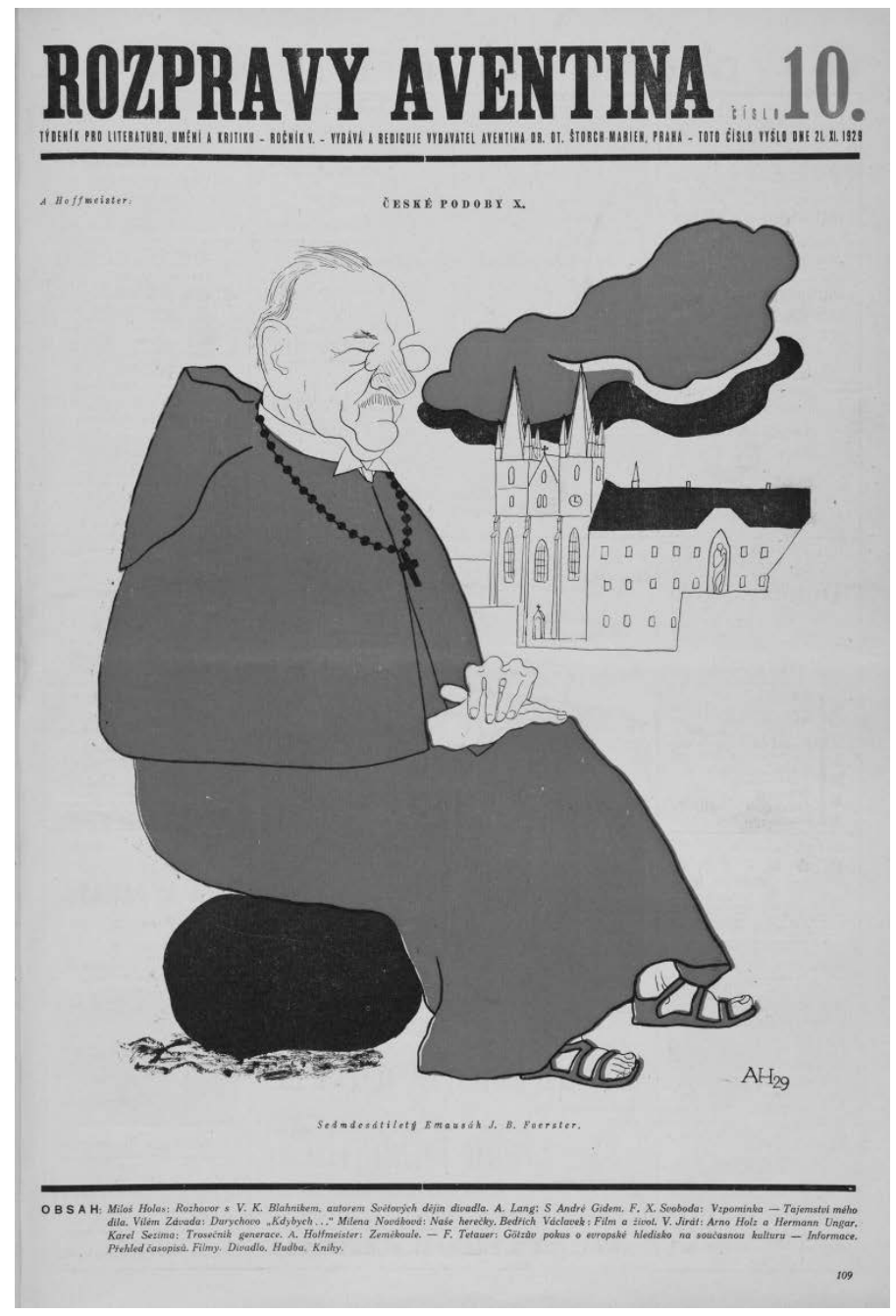

Obr. 2 Adolf Hofmeister: Sedmdesátiletý emauzák Foerster. Rozpravy aventina, roč. 5, č. 10, 21. 11. 1929, s. 109.

stran. [...] Foerster je z těch, kteřri berouce z rukou osudu, pomáhaji nám ukazovati cestu $k$ výšinám. On sám čeká, až budoucnost rozsoudí. Je velikým českým člověkem, velkým umělcem. "42 Jako oddaného Čecha, reprezentanta českého umění, jenž se aktivně podílel na prosazení české hudby u německého publika a u nepřátelské vídeňské reprezentace v čele s vídeňským starostou, se ho snaží vykreslit rovněž Rudolf Jeníček, a předejít tak případným výtkám Foersterovy německé či rakouské kolaborace. ${ }^{43}$

42 STRETIOVÁ, Anna. K 30. prosinci 1919. Hudební revue, 1919-1920, roč. 13, č. 3, s. 89-90.

43 JENÍČEK, Rudolf. J. B. Foerster a česká vídeňská menšina, Hudební revue, 1919-1920, roč. 13, č. 3, s. 93-97. 


\section{Závěr}

Foersterovi se v Československu téměř okamžitě dostává všemožných poct a je jmenován do nejvyšších pozic, jež zastává téměř až do nacistické okupace českých zemí. Do centra pozornosti Univerzální edice, vydavatelství, jež bylo zvláště v první polovině 20. století barometrem životaschopných trendů, přichází nová skladatelská generace či dřive nepovšimnutá avantgarda Druhé vídeňské školy, a také náš Leoš Janáček. Foerster se musí smírit s lokálním prostředím, z něhož se jen těžko nadále udržují kontakty s významnými osobnostmi evropské kultury. Na rozdíl od Vítězslava Nováka však své nové postavení nese důstojně a nepouští se do sporů s každým a o vše. $\mathrm{S}$ vědomím, že už nikdy nebude patřit mezi prvořadé skladatele evropské hudby, úspěšně usiluje o renomé přední postavy domácí kulturní reprezentace a nezpochybnitelné skladatelské autority. Se ztrátou možnosti mezinárodně se prosadit se Foerster spolu s dalšími českými skladateli uchyluje do prostředí české hudební kultury, jež se přes všechny možnosti nabízené národní svobodou v republice prezidenta T. G. Masaryka stává čím dál izolovanějšši. ${ }^{44}$

\section{Bibliography}

\section{Sources}

České muzeum hudby. Fond nenotových rukopisů. Korespondence J. B. Foerstera Alfredovi Schebkovi:

dat. 21. 9. 1910, č. inv. G13219

dat. 3. 10. 1910, č. inv. G13221

dat. 15. 9. 1916, č. inv. G13356

bez dat. [1916], č. inv. G13409

dat. 27. 9. 1916, č. inv. G13358

dat. 31. 12. 1916, č. inv. G13366

dat. 3. 3. 1915, č. inv. G 13222

Wiener Stadt- und Landesbibliothek, Handschriftensammlung, Archiv Universal Edition in Wien, J. B. Foerster:

dopis č. 1, dat. 11. 10. 1909

dopis č. 21, dat. 15. 1. 1916

dopis č. 28, dat. 19. 4. 1917

dopis č. 33, dat. 4. 1. 1920

dopis č. 34, dat. 31. 3. 1920

dopis č. 37 , dat. 8. 11. 1920

dopis č. 38, dat. 26. 12. 1920

44 Zpracování a vydání publikace bylo umožněno díky finanční podpoře Filozofické fakulty Univerzity Palackého v Olomouci v roce 2015 z Fondu pro podporu vědecké činnosti. 
dopis č. 39, dat. 26. 4. 1922

dopis č. 40, dat. 3. 6. 1922

dopis č. 41, dat. 1. 7. 1922

dopis č. 47, dat. 15. 6. 1923

dopis č. 55, dat. 28. 10. 1926

dopis č. 59, dat. 7. 5. 1927

\section{Literature}

ANONYM. Směs. Hudebni revue, 1918-19, roč. 11, č. 3, s. 129-30.

BUCHNER, Alexander. Oskar Nedbal. Soupis pozůstalosti I. Praha: Národní muzeum v Praze. Divadelní oddělení, 1964.

BARTOŠ, Josef (red.). J. B. Foerster - Jeho životni pout' a tvorba 1859-1949. Praha: Orbis, 1949.

Dr. PIHERT [Jindřich Pihert]. Z hudebního života. Národní divadlo. Foersterova Eva. Hudebni revue, 1917-18, roč. 11, č. 4, s. 157-8.

FOERSTER, Josef Bohuslav. Poutnik v cizině. Praha: Orbis, 1947.

HOFMEISTER, Karel. Rod Foersterů. Hudebni revue, 1909, roč. 2, č. 10, s. 489-95.

HOFMEISTER, Adolf. Sedmdesátiletý emauzák Foerster. Rozpravy aventina, roč. 5, č. 10, 21. 11. 1929, s. 109.

JENÍČEK, Rudolf. J. B. Foerster a česká vídeňská menšina, Hudebni revue, 1919-1920, roč. 13, č. 3, s. 93-97.

REITEREROVÁ, Vlasta - VELEK, Viktor. K vídeňským létům (1903-1918) Josefa Bohuslava Foerstera. Hudebni věda, 2010, roč. 47, č. 2-3, s. 167-230.

STRETIOVÁ, Anna. K 30. prosinci 1919. Hudebni revue, 1919-1920, roč. 13, č. 3, s. 89-90.

ŠTĚPÁN, Václav. J. B. Foerster. Ballata pro housle a orchestr, op. 92, Univerzální edice, vyd. pro housle a klavír, 1917. Hudebni revue, 1917-18, roč. 11, č. 8-9, s. 345.

ŠTĚPÁN, Václav. Její pastorkyňa. Odpověd’ na článek prof. Nejedlého. Hudebni revue, 1916-17, roč. 10 , č. 1 , s. $28-40$.

ZÍTEK, Ota. J. B. Foerster. Erotovy masky. Op. 98. Pro klavír na dvě ruce. Vydala Univerzální edice. Hudebni revue, 1917-18, roč. 11, č. 2, s. 68-9.

ZÍTEK, Ota. J. B. Foerster: Debora. V novém nastudování za řízení Otakara Ostrčila. Hudebni revue, 1917-18, roč. 11, č. 8-9, s. 348-50. 